\title{
The Fundamental of Harmony in Gradation, the Formula for Everything
}

\author{
Sigit Haryadi \\ Institut Teknologi Bandung, December \\ 2018
}

Paper DOI 10.31227/osf.io/z2rvj

\section{Citations}

\begin{abstract}
APA: Haryadi, S. (2018, December 6). The Fundamental of Harmony in Gradation, the Formula for Everything. Retrieved from osf.io/preprints/inarxiv/z2rvj

MLA: Haryadi, Sigit. "The Fundamental of Harmony in Gradation, the Formula for Everything." INA-Rxiv, 6 Dec. 2018. Web.

Chicago: Haryadi, Sigit. 2018. "The Fundamental of Harmony in Gradation, the Formula for Everything." INA-Rxiv. December 6. osf.io/preprints/inarxiv/z2rvj.
\end{abstract}

\begin{abstract}
The paper explains the fundamentals of Harmony in Gradation, a formula and the concept that we found on April 28, 2018, which we originally called as Haryadi Index, which we are promoting to be "the Formula for Everything". In detail, the paper explains the background of the findings, formulas, reasons, and methods of using Harmony in Gradation in all branches of science.
\end{abstract}

\section{Preface}

\section{Formula for Everything, it's My Turn Trying to Make It}

The mathematical formula is not just a combination of letters, numbers, and symbols but is very closely related to a sense of beauty, fairness, health, sciences, and human prosperity. This is what I want to say on my website or blog: Harmony in Gradation: The Formula for Everything.

It began with anxiety when observing the cellular telecommunication industry in Indonesia over the past 15 years, where there were dozens of operators that were not sustainable and forced to go bankrupt because they were unable to face an unfair competition, where the economic loss had reached tens of billions of US dollars. Finally, on April 28, 2016, I found a formula that initially named as the Haryadi Index and promotes it to replace the Herfindahl Index, the formula proposed by the USA professor in the field of Economic Law in 1950.

The purpose of the Herfindahl Index is to measure the Concentration Level. Then, if it is found that the Concentration Level in an industry for a certain period of time is already very high, the Economic Judge can decide to do a merger or the unification of several companies that have a low market, with the aim of saving the assets of small companies that will no longer be able to withstand an unfair competition. Unfortunately, so far as the existing formula is not able to prove that if the merger is carried out it will reduce the Concentration Level so that Economic Judges are hesitant to take action. On the other hand, my formula is proven to show the competition level between companies or factories in the industry more accurate and precise.

Three months after I discovered the Haryadi Index, I just realized that the formula was a combination of the Herfindahl Index with the Gini Index, a formula made by the Italian professor of sociology in 1909 , to measure the level of income inequality. Like the Herfindahl Index, the Gini Index also has the same fate. And, it is criticized by practitioners because it is considered inaccurate, but is defended by academics, doctors, and professors in universities throughout the world.

So, to that extent, I believe that my formula can be applied to three areas of science: the science of law, sociology of science, and the science of Economics. 
Sometime later, forgetting exactly, I tried to apply my formula to the fourth field of science, Statistics, as an alternative substitute or a supplement to the Pearson correlation formula, which was compiled in the 1890s. Like the Herfindahl Index and the Gini Index, the Pearson correlation is also much criticized by practitioners because it is considered inaccurate, the difference is that there are many academics, who have made the new formulas as an alternative to the Pearson correlation.

Then, forgetting exactly, I tried to apply my formula to the fifth field of science, this time is my own field of expertise, which Telecommunications engineering, exactly related to resource allocation in $5 \mathrm{G}$ networks with the aim of controlling and improving its performance. Because it was applied to my own field of expertise, I became more aware of the philosophy and fundamentals of my formula, and then I have replaced its name to become "the Harmony in Gradation".

The use of the word "the harmony" is because I was inspired by the philosophy that intends the Herfindahl Index to measure the level of fairness of competition in an industry, while "the gradation" is sad because I was inspired by the philosophy that intends of the Gini Index to measure the degree of inequality of income. As I have mentioned before, the formula without my realizing when I found it, is a combination of the Herfindahl Index and Gini Index.

Then, I have begun to believe that the Harmony in Gradation is the Formula for Everything, a formula that can be applied to all branches of science and life. The reason that Harmony in Gradation is the Formula for Everything because only formulas contain at the same time the two opposing elements, which the Harmony and the Gradation, which can produce an accurate, and precise calculation results representing the nature or property of an event, union, random variable or a system.

There are three ways to implement Harmony in Gradation to be the Formula for Everything, first is directly to replace the existing formula, the second is to measure the Harmony Level of the union or random variable, and the third is to revise the existing formula so that the new formula has two elements at once, which "the harmony" and "the Gradation".

So far on my website, Harmony in Gradation: The Formula for Everything, I have created 14 internet calculators that have been promoted to be used in in ten branches of science, among others in: sciences of Economic Law (replacing Herfindahl Index), Economic Sociology (replacing Gini Index), Statistics (other alternatives to Pearson correlation and proposing new correlation techniques, called the Equality Correlation), Information Technology (revising Claude Shannon's formula), Taxation (no existing formula), Telecommunication technology (no existing formula), Consistency test (replacing the Pauli \& Kraepelin formula), and others.

Specifically, in the fields of Physics and Astronomy, I propose a new postulate as the key to finding the Theory of Everything (TOE), that is "There cannot be a perfect equilibrium of a pair of objects in a union if we do not consider all objects in the union", as I described in Physics and Astronomy equilibrium index.

Now, as long as I live in a healthy life, I still want to develop the implementation of Harmony in Gradation in various branches of science, at least as a proposal to be investigated more deeply by experts in each branch of sciences. I hope that what I have done in the past two and a half years, and hope that it will continue, has benefits for a better human life in the future. 


\section{The Formula}

The need to accurately calculate the future of pair of objects will be answered with the "Haryadi Index" or "Harmony in Gradation", where the formula is to have two opposing elements, the "Harmony" element representing the equilibrium and the "Gradation" element that represents an imbalance.

Here is a formula of "the Haryadi Index" or "the Harmony in Gradation":

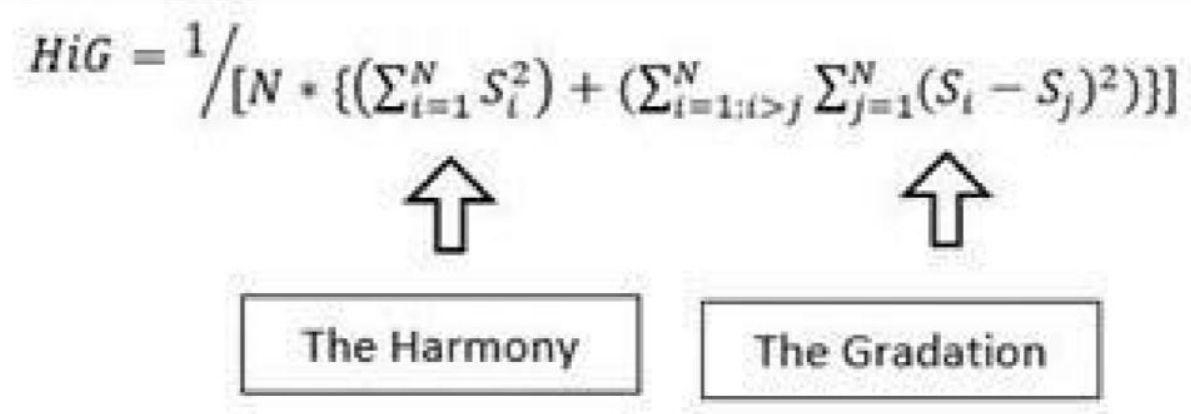

Where

$$
\text { Element Strength }=\mathrm{S}_{i}=\frac{x_{i}}{\left(\sum_{i=1}^{N} x_{i}\right)}
$$

Note: HiG is "the Harmony in Gradation" of a random variable (or set) which has a sample population (or subset) $=\mathrm{N}$, and Si is "the Share" of each sample (or subset) = comparison between strengths or the value of each sample (or subset) with the total strength of the random (or set) variable

Examples of Harmony in Gradation formula are given as follows:

1) In the union consist of two elements: $\mathrm{HI}(2)=1 /\left[2\left\{\mathrm{~S}_{1}{ }^{2}+\mathrm{S}_{2}{ }^{2}+\left(\mathrm{S}_{2}-\mathrm{S}_{1}\right)^{2}\right\}\right]$

2) In the union consist of three elements: $\mathrm{HI}(3)=1 /\left[3\left\{\mathrm{~S}_{1}{ }^{2}+\mathrm{S}_{2}{ }^{2}+\mathrm{S}_{3}{ }^{2}+\left(\mathrm{S}_{2}-\mathrm{S}_{1}\right)^{2}\right.\right.$ $\left.\left.+\left(\mathrm{S}_{3}-\mathrm{S}_{1}\right)^{2}+\left(\mathrm{S}_{3}-\mathrm{S}_{2}\right)^{2}\right\}\right]$

3) In the union consist of four elements: $\mathrm{HI}(4)=1 /\left[4\left\{\mathrm{~S}_{1}{ }^{2}+\mathrm{S}_{2}{ }^{2}+\mathrm{S}_{3}{ }^{2}+\mathrm{S}_{4}{ }^{2}+\left(\mathrm{S}_{2}-\right.\right.\right.$ $\left.\left.\left.\mathrm{S}_{1}\right)^{2}+\left(\mathrm{S}_{3}-\mathrm{S}_{1}\right)^{2}+\left(\mathrm{S}_{4}-\mathrm{S}_{1}\right)^{2}+\left(\mathrm{S}_{3}-\mathrm{S}_{2}\right)^{2}+\left(\mathrm{S}_{4}-\mathrm{S}_{2}\right)^{2}+\left(\mathrm{S}_{4}-\mathrm{S}_{3}\right)^{2}\right\}\right]$

4) In the union consist of five elements: $\mathrm{HI}(5)=1 /\left[5 \mathrm{SS}_{1}{ }^{2}+\mathrm{S}_{2}{ }^{2}+\mathrm{S}_{3}{ }^{2}+\mathrm{S}_{4}{ }^{2}+\mathrm{S}_{5}{ }^{2}\right.$ $+\left(\mathrm{S}_{2}-\mathrm{S}_{1}\right)^{2}+\left(\mathrm{S}_{3}-\mathrm{S}_{1}\right)^{2}+\left(\mathrm{S}_{4}-\mathrm{S}_{1}\right)^{2}+\left(\mathrm{S}_{5}-\mathrm{S}_{1}\right)^{2}+\left(\mathrm{S}_{3}-\mathrm{S}_{2}\right)^{2}+\left(\mathrm{S}_{4}-\mathrm{S}_{2}\right)^{2}+\left(\mathrm{S}_{5}-\mathrm{S}_{2}\right)^{2}+\left(\mathrm{S}_{4}{ }^{-}\right.$ $\left.\left.\left.\mathrm{S}_{3}\right)^{2}+\left(\mathrm{S}_{5}-\mathrm{S}_{3}\right)^{2}+\left(\mathrm{S}_{5}-\mathrm{S}_{4}\right)^{2}\right\}\right]$

5) In the union consist of six elements: $\mathrm{HI}(6)=1 /\left[6\left\{\mathrm{~S}_{1}{ }^{2}+\mathrm{S}_{2}{ }^{2}+\mathrm{S}_{3}{ }^{2}+\mathrm{S}_{4}{ }^{2}+\mathrm{S}_{5}{ }^{2}\right.\right.$ $+\mathrm{S}_{6}{ }^{2}+\left(\mathrm{S}_{2}-\mathrm{S}_{1}\right)^{2}+\left(\mathrm{S}_{3}-\mathrm{S}_{1}\right)^{2}+\left(\mathrm{S}_{4}-\mathrm{S}_{1}\right)^{2}+\left(\mathrm{S}_{5}-\mathrm{S}_{1}\right)^{2}+\left(\mathrm{S}_{6}-\mathrm{S}_{1}\right)^{2}+\left(\mathrm{S}_{3}-\mathrm{S}_{2}\right)^{2}+\left(\mathrm{S}_{4}-\mathrm{S}_{2}\right)^{2}$ $+\left(\mathrm{S}_{5}-\mathrm{S}_{2}\right)^{2}+\left(\mathrm{S}_{6}-\mathrm{S}_{2}\right)^{2}+\left(\mathrm{S}_{4}-\mathrm{S}_{3}\right)^{2}+\left(\mathrm{S}_{5}-\mathrm{S}_{3}\right)^{2}+\left(\mathrm{S}_{6}-\mathrm{S}_{3}\right)^{2}+\left(\mathrm{S}_{5}-\mathrm{S}_{4}\right)^{2}+\left(\mathrm{S}_{6}-\mathrm{S}_{4}\right)^{2}+\left(\mathrm{S}_{6}-\right.$ $\left.\left.\left.S_{5}\right)^{2}\right\}\right]$

6) In the union consist of seven elements: $\mathrm{HI}(7)=1 /\left[7\left\{\mathrm{~S}_{1}{ }^{2}+\mathrm{S}_{2}{ }^{2}+\mathrm{S}_{3}{ }^{2}+\mathrm{S}_{4}{ }^{2}+\right.\right.$ $\mathrm{S}_{5}{ }^{2}+\mathrm{S}_{6}{ }^{2}+\mathrm{S}_{7}{ }^{2}+\left(\mathrm{S}_{2}-\mathrm{S}_{1}\right)^{2}+\left(\mathrm{S}_{3}-\mathrm{S}_{1}\right)^{2}+\left(\mathrm{S}_{4}-\mathrm{S}_{1}\right)^{2}+\left(\mathrm{S}_{5}-\mathrm{S}_{1}\right)^{2}+\left(\mathrm{S}_{6}-\mathrm{S}_{1}\right)^{2}+\left(\mathrm{S}_{7}-\mathrm{S}_{1}\right)^{2}+$ $\left(\mathrm{S}_{3}-\mathrm{S}_{2}\right)^{2}+\left(\mathrm{S}_{4}-\mathrm{S}_{2}\right)^{2}+\left(\mathrm{S}_{5}-\mathrm{S}_{2}\right)^{2}+\left(\mathrm{S}_{6}-\mathrm{S}_{2}\right)^{2}+\left(\mathrm{S}_{7}-\mathrm{S}_{2}\right)^{2}+\left(\mathrm{S}_{4}-\mathrm{S}_{3}\right)^{2}+\left(\mathrm{S}_{5}-\mathrm{S}_{3}\right)^{2}+\left(\mathrm{S}_{6}-\right.$ $\left.\left.\left.\mathrm{S}_{3}\right)^{2}+\left(\mathrm{S}_{7}-\mathrm{S}_{3}\right)^{2}+\left(\mathrm{S}_{5}-\mathrm{S}_{4}\right)^{2}+\left(\mathrm{S}_{6}-\mathrm{S}_{4}\right)^{2}+\left(\mathrm{S}_{7}-\mathrm{S}_{4}\right)^{2}+\left(\mathrm{S}_{6}-\mathrm{S}_{5}\right)^{2}+\left(\mathrm{S}_{7}-\mathrm{S}_{5}\right)^{2}+\left(\mathrm{S}_{7}-\mathrm{S}_{6}\right)^{2}\right\}\right]$

7) In the union consist of eight elements: $\mathrm{HI}(8)=1 /\left[8 \mathrm{~S}_{1}{ }^{2}+\mathrm{S}_{2}{ }^{2}+\mathrm{S}_{3}{ }^{2}+\mathrm{S}_{4}{ }^{2}+\right.$ $\mathrm{S}_{5}{ }^{2}+\mathrm{S}_{6}{ }^{2}+\mathrm{S}_{7}{ }^{2}+\mathrm{S}_{8}{ }^{2}+\left(\mathrm{S}_{2}-\mathrm{S}_{1}\right)^{2}+\left(\mathrm{S}_{3}-\mathrm{S}_{1}\right)^{2}+\left(\mathrm{S}_{4}-\mathrm{S}_{1}\right)^{2}+\left(\mathrm{S}_{5}-\mathrm{S}_{1}\right)^{2}+\left(\mathrm{S}_{6}-\mathrm{S}_{1}\right)^{2}+\left(\mathrm{S}_{7}-\right.$ $\left.\mathrm{S}_{1}\right)^{2}+\left(\mathrm{S}_{8}-\mathrm{S}_{1}\right)^{2}+\left(\mathrm{S}_{3}-\mathrm{S}_{2}\right)^{2}+\left(\mathrm{S}_{4}-\mathrm{S}_{2}\right)^{2}+\left(\mathrm{S}_{5}-\mathrm{S}_{2}\right)^{2}+\left(\mathrm{S}_{6}-\mathrm{S}_{2}\right)^{2}+\left(\mathrm{S}_{7}-\mathrm{S}_{2}\right)^{2}+\left(\mathrm{S}_{8}-\mathrm{S}_{2}\right)^{2}+$ $\left(\mathrm{S}_{4}-\mathrm{S}_{3}\right)^{2}+\left(\mathrm{S}_{5}-\mathrm{S}_{3}\right)^{2}+\left(\mathrm{S}_{6}-\mathrm{S}_{3}\right)^{2}+\left(\mathrm{S}_{7}-\mathrm{S}_{3}\right)^{2}+\left(\mathrm{S}_{8}-\mathrm{S}_{3}\right)^{2}+\left(\mathrm{S}_{5}-\mathrm{S}_{4}\right)^{2}+\left(\mathrm{S}_{6}-\mathrm{S}_{4}\right)^{2}+\left(\mathrm{S}_{7}-\right.$ $\left.\left.\left.\mathrm{S}_{4}\right)^{2}+\left(\mathrm{S}_{8}-\mathrm{S}_{4}\right)^{2}+\left(\mathrm{S}_{6}-\mathrm{S}_{5}\right)^{2}+\left(\mathrm{S}_{7}-\mathrm{S}_{5}\right)^{2}+\left(\mathrm{S}_{8}-\mathrm{S}_{5}\right)^{2}+\left(\mathrm{S}_{7}-\mathrm{S}_{6}\right)^{2}+\left(\mathrm{S}_{8}-\mathrm{S}_{6}\right)^{2}+\left(\mathrm{S}_{8}-\mathrm{S}_{7}\right)^{2}\right\}\right]$ 


\section{Case Study 1: Calculation of Competition between Mobile \\ Telecommunications Providers}

For example in a mobile telecommunications industry consists of four providers, where there is the information about the market as follows: the market of the provider $A=7$ billion $\$$; provider $B=6$ billion $\$$; provider $C$ $=4$ billion $\$$, and providers $D=3$ billion $\$$. Determine the level of competition using the Harmony in Gradation Index.

Solution:

The total market of 4 providers is $7+6+4+3=20$ billion $\$$

Element-strength $I=$ Market share of provider $A=7 / 20=0.35=S_{1}$ Element-strength $I I=$ Market share of provider $B=6 / 20=0.3=S_{2}$ Element-strength III $=$ Market share of provider $C=4 / 20=0.2=\mathrm{S}_{3}$ Element-strength IV = Market share of provider $\mathrm{C}=3 / 20=0.15=\mathrm{S}_{4}$ Harmony in Gradation Index $=\mathrm{HI}(4)=1 /\left[4\left\{\mathrm{~S}_{1}^{2}+\mathrm{S}_{2}^{2}+\mathrm{S}_{3}^{2}+\mathrm{S}_{4}{ }^{2}+\left(\mathrm{S}_{2}\right.\right.\right.$ $\left.\left.\left.\mathrm{S}_{1}\right)^{2}+\left(\mathrm{S}_{3}-\mathrm{S}_{1}\right)^{2}+\left(\mathrm{S}_{4}-\mathrm{S}_{1}\right)^{2}+\left(\mathrm{S}_{3}-\mathrm{S}_{2}\right)^{2}+\left(\mathrm{S}_{4}-\mathrm{S}_{2}\right)^{2}+\left(\mathrm{S}_{4}-\mathrm{S}_{3}\right)^{2}\right\}\right]=\mathrm{HI}(4)=$ $1 /\left[4\left\{0.35^{2}+0.3^{2}+0.2^{2}+0.15^{2}+(0.2-0.15)^{2}+(0.3-0.15)^{2}+(0.35-\right.\right.$ $\left.\left.0.15)^{2}+(0.3-0.2)^{2}+(0.35-0.15)^{2}+(0.36-0.3)^{2}\right\}\right]=0.67(=67 \%$ of the perfect)|

\section{Case Study 2: Calculation of Equality-Correlation.}

Given the following data:

\begin{tabular}{|c|c|c|c|c|}
\hline i & P & Q & R & S \\
\hline 1 & 3 & 1,2 & 10 & 25 \\
\hline 2 & 4 & 1,1 & 8 & 51 \\
\hline 3 & 5 & 1,3 & 9 & 46 \\
\hline 4 & 7 & 1,4 & 10 & 40 \\
\hline 5 & 10 & 1,1 & 11 & 25 \\
\hline
\end{tabular}

Evaluate the degree of correlation between the $\left(100+3 P+10^{\circ}\right)$ and $\left(3 R^{*} \log S\right)$ using the Harmony in Gradation Index.

\section{SOLUTION:}

To evaluate the degree of correlation between $\left(100+3 \mathrm{P}+10^{\circ}\right)$ and $\left(3 \mathrm{R}^{*} \log \mathrm{S}\right)$ by implementing the Harmony in Gradation Index, it must be calculated first, the element strength = element value divided by $\Sigma$ (all elements value). The element value in this case $=\left(100+3 \mathrm{P}+10^{\circ}\right) /(3 \mathrm{R} * \log S)$.

Data is processed as follows:

Then:

\begin{tabular}{|r|r|r|r|}
\hline $\mathrm{i}$ & $100+3 \mathrm{P}+10^{9}$ & $3 \mathrm{R}^{*} \log S$ & $\left(100+3 \mathrm{P}+10^{\circ}\right) /\left(3 \mathrm{R}^{*} \log \mathrm{S}\right)$ \\
\hline 1 & 124.849 & 41.938 & 2.977 \\
\hline 2 & 124.589 & 40.982 & 3.040 \\
\hline 3 & 134.953 & 44.894 & 3.006 \\
\hline 4 & 146.119 & 48.062 & 3.040 \\
\hline 5 & 142.589 & 46.132 & 3.091 \\
\hline & $\Sigma$ & & 15.154 \\
\hline
\end{tabular}

Element-strength $I=\mathrm{S}_{1}=2.977 / 15.154=0.196 ;$ Element-strength $I I=\mathrm{S}_{2}=3.040 / 15.154=0.201$ Element-strength $I I I=S_{3}=3.006 / 15.154=0.198 ;$ Element-strength $I V=S_{4}=3.040 / 15.154=0.201$ Element-strength $V=\mathrm{S}_{5}=3.091 / 15.154=0.204$

Then, the degree of correlation using the Harmony in Gradation Index $=\mathrm{HI}(5)=1 /\left[5\left\{\mathrm{~S}_{1}{ }^{2}+\mathrm{S}_{2}{ }^{2}+\mathrm{S}_{3}{ }^{2}\right.\right.$ $+\mathrm{S}_{4}{ }^{2}+\mathrm{S}_{5}^{2}+\left(\mathrm{S}_{2}-\mathrm{S}_{1}\right)^{2}+\left(\mathrm{S}_{3}-\mathrm{S}_{1}\right)^{2}+\left(\mathrm{S}_{4}-\mathrm{S}_{1}\right)^{2}+\left(\mathrm{S}_{5}-\mathrm{S}_{1}\right)^{2}+\left(\mathrm{S}_{3}-\mathrm{S}_{2}\right)^{2}+\left(\mathrm{S}_{4}-\mathrm{S}_{2}\right)^{2}+\left(\mathrm{S}_{5}-\mathrm{S}_{2}\right)^{2}+\left(\mathrm{S}_{4}-\mathrm{S}_{3}\right)^{2}+\left(\mathrm{S}_{5}\right.$ $\left.\left.\left.\mathrm{S}_{3}\right)^{2}+\left(\mathrm{S}_{5}-\mathrm{S}_{4}\right)^{2}\right\}\right]=1 /\left[5\left\{0.196^{2}+0.201^{2}+0.198^{2}+0.201^{2}+0.204^{2}+(0.201-0.196)^{2}+(0.198-\right.\right.$ $0.196)^{2}+(0.201-0.196)^{2}+(0.204-0.196)^{2}+(0.198-0.201)^{2}+(0.201-0.201)^{2}+(0.204-0.201)^{2}+$ $(0.201-0.198)^{2}+(0.204-0.198)^{2}=0.9989(=99.89 \%$ of the perfect $)$.

\section{The Fundamental of Harmony in Gradation}

\subsection{Background}

The Harmony in Gradation is the formula that has been made by Sigit Haryadi on April 28, 2016, which was originally named as "Haryadi Index" since only focus to use in the Competition Law field, to replace the Herfindahl-Hirschman Index (HHI). But, after studying for two years, the inventor was very 
confident that the formula can be used as an alternative to replace many existing methods in all branches of science, because in the formula both contain two contradictory things that no one has ever thought to merge them, namely "the Harmony" and "the Gradation", on the other hand, the existing formulas contain only that one element.

More specifically, pay close attention to the Images of Equalizer which is the closest form of the Harmony in Gradation, where each calculator that is on my website is a representation of one or more of the equalizer images.

\subsection{Simple Explanation}

A painting or natural landscape that has a combination of shapes and colors will look very beautiful if there is a harmony of the gradation of the shapes and colors that lie in suitable positions. Also, a musical composition that has a combination of tone and rhythm will sound very melodious if there is a harmony of the tonal gradation and the rhythm that lies in the appropriate time sequence. Then, inspired by paintings, natural scenery, and music, we suppose that most of the mathematical formula in all sciences should have two elements simultaneously that "the Harmony" and "the Gradation".

\subsection{The Excellence of formulas that are not found in other formulas}

It has been proven, the existence of "the harmony" and "the gradation" at the same time on a formula when used to analyze a Union or a random variable is to produce an index or level that accurately and precisely represents the "harmony level" of the Union or random variable regardless of the population. This means that an index equal to one is showing the perfect conditions of the harmony level, a value equal to 0.95 means that the harmony level is 0.95 of the perfect, a value equal to 0.75 indicates the harmony level is equal to 0.75 of the perfect, and so on. The consequence, the Harmony in Gradation will produce an index that represents the nature of the union or the random variable very accurately and precisely.

\subsection{When Should to Use Harmony in Gradation}

The branch of science that is worth considering the use of Harmony in Gradation is that it uses "the level of harmony" which represents "the beauty" as the keyword of the research, which in each branch of science are called in different terms such as "level of balance", "equilibrium level", "stability level", "level of parity", "equipoise level", "level of competition", "level of justice", "fairness level", "level of correlation", "entropy", "level of performance", "Level of quality", "level of certainty", "level of health", "level of similarity", "confidence level", "level of consistency", "level of equity", "level of equality", and others. And, don't forget, since some branches of science prefer to use the negative of these terms, then the spirit of Harmony in Gradation also corresponds to the terms of "the level of imbalance", "the level of concentration", "the level of injustice", "unfairness level", "complement level", "counterbalance level", "level of uncertainty", "level of relativity", "level of inequality", "level of inequity", and others.

\subsection{How to Implement Harmony in Gradation}

There are three ways to use the Harmony in Gradation formula.

I. First, is to replace the existing formula.

II. Second, the Harmony in Gradation formula is used to calculate "the harmony level" of the union or random variables that are being observed, which are formed or defined through an existing formula or a formula that was just made. 
III. Third, the spirit of Harmony in Gradation is utilized, in the sense that the existing formula is modified in such a way so that in the same time it has the two elements which "the Harmony" and "the Gradation".

\subsection{What to do if we have a Low Level of Harmony}

In essence, the name of the formula is the Harmony in Gradation, not the Gradation in Harmony because the goal is to form the harmony.

Moreover, when we are analyzing a Union or a random variable that has the harmony level that we consider too low and want to increase it, then there are several alternatives that can be done.

I. First, combining several elements that have relatively small strength so that the union population will be less but there will be a balance of power between the existing elements that have great power with new elements which are a combination of small elements.

II. Second, let the elemental population not change, but shift or give a portion of the strength of the elements that are relatively large to the small elements.

III. Third, combines the first and second ways.

IV. The fourth way, if you have a Union or random variable that is less harmonious, then we put it side by side and compare to the other Union or random variable which also not harmonious, but these two unions have the same relative strength distribution so that the combination of these Unions will appear harmonious.

V. Fifth, is done if we cannot change the harmony level of pairs of objects and/or waves, and can only observe, then we should use the Harmony in Gradation to examine what will happen in the future in pairs of objects and/or waves that will change or move continuously caused by disharmony that is slightly less perfect between them.

VI. It may take the sixth method, the seventh strategy and so on.

\section{Calculators of the Harmony in Gradation}

The following below have been made several internet calculators to implement Harmony in Gradation in various fields of science:

1) Performance Simulation of $5 \mathrm{G}$ Cellular Network Explanation

2) Measurement of Competition Level in the Industry Explanation

3) Consistency Test Explanation

4) Measurement of the Income Equality Index and Level Explanation

5) Channel Cavity on Data Communications Explanation

6) Measurement Index of "the Fairness over Inequality" Explanation

7) Equality Correlation Explanation

8) The Human Development Index Inequality Explanation

9) Linear Regression Without Intercept Explanation

10)Smart Estimation ver. H.1.0 Explanation

11) The Equity Level of an Internet Service Explanation

12) Competition Levels among Students Explanation

13) Fair Policy of TAX RATE Explanation

14) A New Equilibrium Index for the science of Physics and Astronomy Explanation 


\section{Examples to Show that Harmony in Gradation is more Accurate than the Existing Formulas}

\begin{tabular}{|c|c|c|c|c|c|c|c|}
\hline \multicolumn{8}{|c|}{ Example of the Comparison between Harmony in Gradation and Herfindahl Index } \\
\hline \multicolumn{4}{|c|}{ Before Merging } & \multicolumn{4}{|c|}{ After Merging } \\
\hline Firm & $\begin{array}{l}\text { Market } \\
\text { Before } \\
\text { Merging }\end{array}$ & Herfindahl Index & $\begin{array}{l}\text { Harmony in } \\
\text { Gradation Index }\end{array}$ & Firm & $\begin{array}{l}\text { Market } \\
\text { After } \\
\text { Merging }\end{array}$ & $\begin{array}{l}\text { Herfindahl } \\
\text { Index }\end{array}$ & $\begin{array}{l}\text { Harmony in } \\
\text { Gradation } \\
\text { Index }\end{array}$ \\
\hline A & 0.32 & \multirow{5}{*}{$\begin{array}{c}\text { Index }=0.257 \\
\text { indicates a high } \\
\text { concentration (An } \\
\mathrm{H} \text { above } 0.25 \text { ) }\end{array}$} & \multirow{5}{*}{$\begin{array}{c}\text { Index }=0.371 \\
\text { indicates an } \\
0.371 \text { of perfect } \\
\text { competition (= } \\
\text { unfair) }\end{array}$} & A & 0.32 & \multirow{5}{*}{$\begin{array}{l}\text { Index }=0.267 \\
\text { indicates a high } \\
\text { concentration, } \\
\text { a little worse } \\
\text { than before } \\
\text { merged }\end{array}$} & \multirow{5}{*}{$\begin{array}{c}\text { Index }=0.75 \\
\text { indicates an } \\
0.75 \text { of perfec } \\
\text { competition (= } \\
\quad \text { fair) }\end{array}$} \\
\hline B & 0.29 & & & $B$ & 0.29 & & \\
\hline C & 0.24 & & & C & 0.24 & & \\
\hline D & 0.05 & & & $D+E$ & 0.15 & & \\
\hline $\mathrm{E}$ & 0.1 & & & & & & \\
\hline
\end{tabular}

\begin{tabular}{|c|c|c|c|c|c|c|c|}
\hline \multicolumn{8}{|c|}{ Example of the Comparison between Harmony in Gradation and Gini Index } \\
\hline \multicolumn{4}{|c|}{ Country A } & \multicolumn{4}{|c|}{\begin{tabular}{|c|} 
Country B \\
\end{tabular}} \\
\hline Group & \begin{tabular}{c|} 
Income \\
(\$)
\end{tabular} & \begin{tabular}{c|} 
Calculation Using \\
Gini Coefficient
\end{tabular} & \begin{tabular}{c|} 
Calculation Using \\
Harmony in Gradation
\end{tabular} & Group & $\begin{array}{c}\text { Income } \\
\text { (\$) }\end{array}$ & \begin{tabular}{|c|} 
Calculation Using \\
Gini Coefficient
\end{tabular} & $\begin{array}{c}\text { Calculation Using } \\
\text { Harmony in Gradation }\end{array}$ \\
\hline A & 20,000 & \multirow{6}{*}{$\begin{array}{c}\text { Income } \\
\text { Inequality }=\text { Gini } \\
\text { Cofficient }=0.2\end{array}$} & \multirow{6}{*}{$\begin{array}{l}\text { Income equality = } \\
\text { Harmony in Gradation } \\
=0.57 \text { of perfect } \\
\text { equality }\end{array}$} & A & 9,000 & \multirow{6}{*}{$\begin{array}{c}\text { Income } \\
\text { Inequa lity }=\text { Gini } \\
\text { Cofficient }=0.2\end{array}$} & \multirow{6}{*}{$\begin{array}{c}\text { Income equality = } \\
\text { Harmony in Gradation = } \\
0.50 \text { of perfect equality }\end{array}$} \\
\hline B & 30,000 & & & B & 40,000 & & \\
\hline C & 40,000 & & & $\mathrm{C}$ & 48,000 & & \\
\hline $\mathrm{D}$ & 50,000 & & & $\mathrm{D}$ & 48,000 & & \\
\hline $\mathrm{E}$ & 60,000 & & & $\mathrm{E}$ & 55,000 & & \\
\hline Total & 200,000 & & & & 200,000 & & \\
\hline \multicolumn{8}{|c|}{$\begin{array}{l}\text { Note: Two countries that have a different income in equality are said to have the same Gini Coefficient, and the number } \\
(=0.2) \text { do not accurately show the level of inequality. On the other hand, Harmony in Gradation is more able to show } \\
\text { differences in income equality and the indexes }(0.57 \text { and } 0.50) \text { shows accurately the equality level of the perfect level. }\end{array}$} \\
\hline
\end{tabular}

\begin{tabular}{|c|c|c|c|}
\hline \multicolumn{4}{|c|}{ Example of the Comparison between Harmony in Gradation and Pearson } \\
\hline $\begin{array}{l}\text { Voltage } \\
\text { in } \\
\text { millivolts }\end{array}$ & \begin{tabular}{|l} 
Current \\
in \\
amperes
\end{tabular} & Linear Pearson Regression & $\begin{array}{l}\text { Harmony in Gradation Regression without } \\
\text { intercept }\end{array}$ \\
\hline 100 & 23 & \multirow{6}{*}{$\begin{array}{l}\text { Regression Equation: [Voltage }=0.1 \\
\text { Current }+4.46 \text { ] indicates that voltage } \\
=4.46 \text { millivolts when there is no } \\
\text { electric current, but } r=0.9956\end{array}$} & \multirow{6}{*}{$\begin{array}{c}\text { Regression Equation: [Voltage }=0.12 \\
\text { Current] indicates that voltage }=0 \text { millivolts } \\
\text { when there is no electric current, and } r= \\
\text { harmony in gradation index }=0.48 \text { of } \\
\text { perfect }\end{array}$} \\
\hline 300 & 28 & & \\
\hline 600 & 65 & & \\
\hline 1000 & 109 & & \\
\hline 2000 & 187 & & \\
\hline 3000 & 315 & & \\
\hline \multicolumn{4}{|c|}{$\begin{array}{l}\text { Note: in the example above, there is an inaccurate measurement sample since referring to the } \\
\text { [Voltage = Resistance } x \text { Current] formula, then the voltage should be zero when there is no electric } \\
\text { current. However, the use of existing methods produces a high level of correlation because it refers } \\
\text { to the wrong regression. }\end{array}$} \\
\hline
\end{tabular}




\section{Notes}

In order to understand the concept of "Haryadi Index" or "Harmony in Gradation" that became the spirit of this calculator, please read my writings in the following bibliography.

\section{References}

[1] Sigit Haryadi. (2017). Haryadi Index and Its Applications in Science of Law, Sociology, Economics, Statistics, and Telecommunications. Penerbit Elex Media Komputindo. Jakarta. ISBN: 978-602-02-9895-5.

[2] Sigit Haryadi. (2017). Indeks Haryadi dan Penerapan di Ilmu Hukum, Sosiologi, Ekonomi, Statistik, dan Telekomunikasi. Penerbit Elex Media Komputindo, Jakarta. ISBN: 978-602-02-9896-2

[3] Sigit Haryadi. (2016). Haryadi Index for Competition, Equality and Correlation Evaluation. Penerbit Lantip Safari Media, Bandung, Indonesia. ISBN: 978-602-732313-2

[4] Sigit Haryadi. (2016). Haryadi Index untuk Evaluasi Kompetisi, Kesetaraan dan Korelasi. Penerbit Lantip Safari Media, Bandung, Indonesia. ISBN: 978-602-73231-31

[5] Haryadi, S. (2018, March 29). Estimasi Cerdas Ver-H.1.0. http://doi.org/10.17605/OSF.IO/DHQ9Y

[6] Haryadi, S. (2018, March 29). Smart Estimation Ver-H.1.0. http://doi.org/10.17605/OSF.IO/2TYQK

[7] Sigit Haryadi. (March 17, 2018). The Six 100-year-old Formula Should be Replaced. Researchgate. DOI 10.13140/RG.2.2.21919.66723

[8] Haryadi, S. (2018, March 17). Sepuluh Implementasi Yang Pertama untuk Membuktikan bahwa "The Harmony in Gradation" adalah "The Formula Everything". Retrieved from osf.io/preprints/inarxiv/ja9ve

[9] Haryadi, S. (2018, March 17). The Ten First Implementations to prove that "The Harmony in Gradation" is "The Formula Everything". Retrieved from osf.io/preprints/inarxiv/59szb

[10]Haryadi, S., \& California, S. H. (2018, March 14). New Method to Calculate the Level of Consistency of the Pauli \& Kraepelin Tests. Retrieved from osf.io/preprints/inarxiv/ty326 [11] Haryadi, S., \& California, S. H. (2018, March 14). Metoda Baru Untuk Menghitung

[11]Tingkat Konsistensi pada Tes Pauli \& Kraepelin. Retrieved from osf.io/preprints/inarxiv/qht8j [12] Haryadi, S. (2018, March 6). Calculation the Equity Level of an Internet Service. Retrieved from osf.io/uzcmq

[12]Haryadi, S. (2018, March 6). Perhitungan Tingkat Pemerataan Layanan Internet. Retrieved from osf.io/preprints/inarxiv/rgct3

[13]Dyah Rakhma Ariyanti; Sigit Haryadi. (October 2017). Analysis of Harmony in Gradation Index on 5G Cellular Network Quantitative Analysis. The 11th International Conference on Telecommunication Systems, Services, and Applications, At Lombok, Indonesia.

[14]Haryadi, S. (2017, November). Probabilitas Statistik Untuk Insinyur. Researchgate. DOI: $10.13140 /$ RG.2.2.14304.58885

[15]Haryadi, S. (2018, February 1). Indeks Haryadi dan Prospeknya Untuk Menjadi Suatu "Formula of Everything (versi 31 Desember 2017). Retrieved from osf.io/zex45

[16]Haryadi, S. (2018, February 1). KALKULATOR untuk membuat Regresi Linier Tanpa Intersep. Retrieved from osf.io/emvs7 
[17]Haryadi, S. (2018, February 1). Kalkulator Untuk Mengukur Tingkat Kompetisi di suatu Industri, dengan menggunakan rumus Indeks Haryadi. Retrieved from osf.io/fy7zu

[18]Haryadi, S. (2018, February 17). Calculation the Competition Levels between Students in Class and the Relation to the Teacher or Lecture Fairness in Teaching. Researchgate. DOI: 10.13140/RG.2.2.30359.06569

[19]Haryadi, S. (2018, February 17). Perhitungan Tingkat Kompetisi antar Murid atau Mahasiswa di Kelas dan Kaitannya Dengan Keadilan Guru atau Dosen Dalam Mengajar. Retrieved from osf.io/a894w

[20]Haryadi, S. (2018, February 22). Equality Correlation Calculation. Researchgate. DOI: 10.13140/RG.2.2.22068.76168

[21]Haryadi, S. (2018, February 22). Kalkulator Untuk Menghitung Korelasi Kesetaraan. Retrieved from osf.io/preprints/inarxiv/7r9jy

[22]Haryadi, S. (2018, February 24). Calculation of "Channel Cavity" on Data Communications. Equality Correlation Calculation. Research gate. DOI: 10.13140/RG.2.2.30536.01288

[23]Haryadi, S. (2018, February 24). Perhitungan "Rongga Kanal" pada Komunikasi Data. Retrieved from osf.io/preprints/inarxiv/y3wcg

[24]Haryadi, S. (2018, February 28). Ikhtisar Organisasi Regulasi Telekomunikasi. Retrieved from osf.io/preprints/inarxiv/g9m3k

[25]Haryadi, S. (2018, February 7). Statistik Terapan: Pengujian Regulasi \& Kebijakan Telekomunikasi. Retrieved from osf.io/3pkfw

[26]Haryadi, S. (2018, January 25). Chapter 1. The Concept of Telecommunication Network Performance and Quality of Service. Retrieved from osf.io/mukqb

[27]Haryadi, S. (2018, January 26). Chapter 2 of Network Performance and Quality of Service: Determination of Key Performance Indicator (KPI). Retrieved from osf.io/preprints/inarxiv/6gtnd

[28]Haryadi, S. (2018, January 26). Chapter 3 of Network Performance and Quality of Service: Technical Measurement of a Mobile Network Performance and Quality of Service. Retrieved from osf.io/q4wsz

[29]Haryadi, S. (2018, January 30). Basic Calculation of the Network's Availability and Reliability (Chapter 4 of Network Performance and Quality of Service). Retrieved from osf.io/preprints/inarxiv/z5mwq

[30]Haryadi, S. (2018, March 1). Kebijakan Lisensi Telekomunikasi. Retrieved from osf.io/7wbjf

[31]Haryadi, S. (2018, March 5). Performance Measurement of Internet Service. Retrieved from osf.io/9nsw3

[32]Haryadi, S., \& Riani, W. (2018, March 5). METODE PENETAPAN TARIF PAJAK PENGHASILAN YANG BERKEADILAN. Retrieved from osf.io/preprints/inarxiv/ayg58

[33]Nie Levin Kusuma Adiatma; Sigit Haryadi. (2017, October). Comparison of the Haryadi Index with Existing Method in Competition, Equality, Fairness, and Correlation Level Calculation Case Study: Telecommunication Industry. The 11th International Conference on Telecommunication Systems, Services, and Applications, At Lombok, Indonesia.

[34]Sigit Haryadi. (2017). Calculation of the Mobile Communication Competition using Haryadi Index. DOI: 10.13140/RG.2.2.15634.25280

[35]Sigit Haryadi. (2017). Harmony in Gradation and its prospects as the Formula of Everything (First edition of posts: December 31, 2017). Researchgate.

DOI: $10.13140 /$ RG.2.2.19309.08169 
[36]Sigit Haryadi. (2017). the Equality Correlation Method. Researchgate. DOI: 10.13140/RG.2.2.10443.80169.

[37]Sigit Haryadi. (2017). the Non-Intercept Linear Regression Method. Researchgate. DOI: $10.13140 /$ RG.2.2.18721.71522

[38]Sigit Haryadi. (2017). The Fairness over Inequality Index: Unfairness is Disaster - a notebook of Sigit Haryadi. Researchgate. DOI: 10.13140/RG.2.2.34379.49449.

[39]Sigit Haryadi. (2017, December). Calculator for Measurement the Competition Index \& Level. Researchgate. DOI: 10.13140/RG.2.2.23626.26568

[40]Sigit Haryadi. (2017, December). Calculator for non-intercept linear regression. Researchgate. DOI: 10.13140/RG.2.2.15761.94562.

[41]Sigit Haryadi. (2017, January). Calculation of the Income Equality Levels between Regions using the Haryadi Index. Researchgate. DOI: 10.13140/RG.2.2.36605.77282

[42]Sigit Haryadi. (2018, February). Applied Statistics for Assessment of the Regulation and Policy: case study in Telecommunication Industry. DOI: 10.13140/RG.2.2.15774.02884

[43]Sigit Haryadi; Dyah Rakhma Ariyanti. (October 2017). The Fairness of Resource Allocation and Its Impact on 5G Ultra-Dense Cellular Network Performance. The 11th International Conference on Telecommunication Systems, Services, and Applications, At Lombok, Indonesia.

[44]Westi Riani; Sigit Haryadi. (2017). CALCULATOR for the Government to make the Fair Policy of Tax Rates. Researchgate. DOI: 10.13140/RG.2.2.18550.50246.

[45]Westi Riani; Sigit Haryadi. (2017). the Method of Tax Rate Determination Based On Fairness. Prosiding Seminar Nasional SNaPP2017, Bandung, Indonesia.

[46]Haryadi, S., \& Riani, W. (2018, March 12). Telecommunication Competition and Interconnection. Retrieved from osf.io/preprints/inarxiv/7tfqd

[47]Westi Riani; Sigit Haryadi. (2017). Prosiding SNaPP2017 "THE METHOD OF TAX RATE DETERMINATION BASED ON FAIRNESS". Conference: Seminar Nasional Penelitian dan PKM (SNaPP) 2017At: Bandung, Indonesia.

[48]Sigit Haryadi. (2017). Tantangan Untuk Menerapkan Haryadi Index pada Ilmu Fisika. Jurnal Pendidikan Fisika Sekolah Menengah. Jurnal Pendidikan Fisika Sekolah Menengah. Vol.9/no 1/2017. ISSN: 1979-4959. Available at: https://www.researchgate.net/publication/316683866

[49]Westi Riani; Sigit Haryadi. (2016). Keterbatasan Indeks Gini sebagai Ukuran Ketimpangan Pendapatan dan Solusi Metoda Alternatif. Prosiding SNaPP: Sosial, Ekonomi, dan Humaniora. Tersedia di http://proceeding.unisba.ac.id/index.php/sosial/article/view/383

[50]Haryadi, S., \& Riani, W. (2018, March 19). Pengukuran Ketimpangan Indeks Pembangunan Manusia. Retrieved from osf.io/preprints/inarxiv/x9vjt

[51]Haryadi, S., \& Riani, W. (2018, March 19). Measurement of the Human Development Index Inequality. Retrieved from osf.io/preprints/inarxiv/5r42m

[52]Haryadi, Sigit. 2018. "Always Move to Seek Perfection: The New Equilibrium Index Calculation for the Science of Physics and Astronomy." INA-Rxiv. July 13. osf.io/preprints/inarxiv/8hrnb. 